\section{TIME BANKING IN SPAIN Exploring their Structure, Management and Users' Profile}

\author{
Dr. Carmen Valor \\ Unicersidad Pontificia Comillas. Madrid. Spain. \\ cvalor@upcomillas.es \\ Dr. Eleni Papaoikonomou \\ Rovira and Virgili University. Tarragona. Spain. \\ papaoikonomou@urv.cat
}

Cómo citar este artículo / Citation: Valor, C. and E. Papaoikonomou. 2016. "Time banking in Spain. Exploring their structure, management and users' profile". Revista Internacional de Sociología, 74 (1): e028. Doi: http:// dx.doi.org/10.3989/ris.2016.74.1.028

\begin{abstract}
Time banks (TBs) have experienced significant growth in the last few years in Spain and have been incorporated in the agenda of political parties drawing the attention of national and international media as a solution to the economic crisis. Nevertheless, there is scant empirical evidence about this phenomenon in Spain. After describing the role of TBs in other countries, this paper examines the structure and management of TBs in Spain and develops a taxonomy of them. Additionally, it identifies the goals TBs pursue and the reasons why users join them. To do so, this paper uses a mixedmethod approach consisting of in-depth interviews with 28 TB managers and an online survey of users $(n=270)$. It concludes that TBs are a social-political project rather than a utilitarian-economic project, identifying differences between Spanish TBs and those in other countries.
\end{abstract}

\section{KEYWORDS}

Time banks; Spain; alternative markets; mixed-methods; profile.

\section{BANCOS DE TIEMPO EN ESPAÑA Una exploración de su estructura, gestión y perfil de usuarios}

Copyright: (C) 2016 CSIC. This is an open-access article distributed under the terms of the Creative Commons Attribution-Non Commercial (by-nc) Spain 3.0 License

Received: 23/07/2014. Accepted: 02/12/2014.

Publicación online: 09/02/16

\title{
RESUMEN
}

Los bancos de tiempo han ido ganando importancia en los últimos años, han sido incorporados en programas políticos, y están siendo objeto de atención por la prensa nacional e internacional como una solución a la crisis que atraviesa el país. Sin embargo, poco se sabe de este fenómeno en España. Este trabajo, tras identificar el papel que los bancos de tiempo han jugado en otros países, analiza tanto la estructura y gestión de los bancos, ofreciendo una taxonomía de los mismos, además de examinar los fines para los que se crean y por los que se participa en ellos. Para ello, se recurre a un método mixto: entrevistas en profundidad con 28 gestores de bancos de tiempo y una encuesta online a usuarios $(n=270)$. Se concluye que el fenómeno de los bancos de tiempo en España tiene más de proyecto socialpolítico que económico-utilitario y que mantiene algunas particularidades que lo diferencian de otros países.

\section{Palabras Clave}

Bancos de tiempo; España; mercados alternativos; método mixto; perfil. 


\section{INTRODUCTION}

In the last few years, different complementary currency systems have emerged (Seyfang and Longhurst 2013a; Blanc 2011; Hughes 2005), such as local currencies, barter markets and time banks (TB hereafter). In his typology of complementary currencies, Blanc (2011: 9) describes TBs as schemes that pursue a community purpose and principally aim to contribute to the "well-being, empowerment, autonomy and social exchanges of a given community". As such, the main difference with other community currencies is that TBs are seen as social innovation because they address specific social needs and enhance social aspects of well-being (Seyfang and Longhurst 2013a, b; Blanc 2011; Seyfang 2004).

The functioning of TBs is simple: users provide services to other users thus earning time credits that may be used later to obtain a service that they need (Clary 2008); in turn, the recipient has a debt in time credits and 'repays' by providing a service to the same or a different member of the TB. In this way, time is 'banked' and may be used when the member needs it. Thus, reciprocity is indirect and multilateral in TBs and exchanges are not dyadic, but chain-generalised (Ekeh 1974) or network-generalized (Yamagishi and Cook 1993). These exchanges include a variety of services such as cooking, babysitting and dog walking, among others (Collom, Lasker and Kyriakou 2012; Ozanne and Ozanne 2011; Seyfang 2006). In TBs, time is understood as an alternative type of currency operating as a store of value and a medium of exchange (Boyle 2014). Because time banking is based on tenets of equality, all services are usually equally valued regardless of the service provided, that is, an hour's work for an hour's work (Seyfang and Longhurst 2013b; Dittmer 2013; Collom, Lasker and Kyriakou 2012; Ozanne and Ozanne 2011). However, this also means that exchanges are often limited to services, since it is complicated to define goods' value in time and trade them in TBs (Dittmer 2013; North 2003).

TBs have been limitedly examined in the literature, especially compared to other forms of community currencies (Dittmer 2013) and to our knowledge there is no paper addressing the phenomenon in Spain. Yet, the number of TBs in Spain has grown considerably over the past years until reaching 200 in 2012 (Del Moral 2013) or, according to other sources, 250 (Seyfang and Longhurst 2013a) or 328 (Vivir Sin Empleo 2014). The three main political Spanish parties, the Spanish Socialist Worker Party (PSOE), the People's Party (PP) and the United Left (IU) included the commitment to create TBs in their political agenda, albeit with different aims-youth development, the work-life balance and alternative economy development, respectively (Del Moral 2013). Spanish TBs have appeared frequently in the national and international media in the last two years, where they are presented as an alternative economy in times of recession that allows the unemployed to counteract the negative effects of the crisis (Del Moral 2013; see, inter alia, stories by Eunjung Cha 2012 and Frayer 2012).

Two main streams of research on TBs can be identified. A first group of authors have developed conceptual papers about TBs exploring their potential in a transition to sustainability and the degrowth paradigm (e.g., Dittmer 2013; Seyfang 2006; Hughes 2005). A second group of authors have studied specific TBs, usually one at a time (with the exceptions of Seyfang and Smith 2002 and Collom, Lasker and Kyriakou 2012). Most research has been conducted in English-speaking countries. In the United States, Collom (2007; 2008; 2011) analyzed participants' motivations and benefits, TBs' ability to create social capital, and the results obtained as a tool of inclusion for the elderly. Dubois, Schor and Carfagna (2014) examined the transformatory potential of TBs focusing on the Boston Trade Circle TB. In the UK, Seyfang $(2002 ; 2003)$ examined TBs as a tool for social inclusion. In New Zealand, Ozanne (2010) and Ozanne and Ozanne (2011) studied how TBs helped to strengthen community ties and the types of capital created. Finally, Molnar (2011) evaluated the achievements and challenges of a TB in Sweden. All these authors describe the aims of TBs in these countries, their organisation and management, and users' experience. TBs are said to be chameleonic given that they are instrumental for different purposes in different countries (Collom, Lasker and Kyriakou 2012). Consequently, they are also organized differently in different countries (Seyfang and Longhurst 2013a).

This paper reviews the existing literature to describe the role TBs play in other countries as well as their organisation, drivers and barriers for participation. The results of our empirical study comprising interviews with time brokers of 27 Spanish TBs and of an online survey of Spanish TBs users are then presented. A comparison of Spanish TBs with those of other countries is provided in order to assess similarities and differences.

Such research is timely in the Spanish context because as said above, they have been featured in the media, been included in political agendas, and grown in number. Furthermore, we have examined different types of TBs, some of which have emerged from the recent 15M movement. The narratives of TB managers show that they expect important outcomes from the creation of a TB. Yet our findings provide evidence that the number of exchanges is very limited and that most participants have never carried out a transaction. The main conclusion of this research is that TBs in Spain enjoy more symbolic than material importance, corroborating Dittmer's (2013) claims for TBs' limited potential. This paper will ultimately suggest possible explanations for this contradiction. Given the state of the literature, this paper should be considered exploratory. The findings indicate research lines that should be addressed in future studies. 


\section{THE PHENOMENON OF TIME BANKS AROUND THE WORLD: ORIGINS, PURPOSE AND FUNCTIONING}

TBs were created in the US in the 1980s by the civil rights lawyer Edgar Cahn in response to the erosion of informal neighborhood networks (Seyfang 2002). Cahn's main purpose was to "make social welfare more effective and humane" through what he called "co-production" (Dittmer 2013: 6). His ideas served as basis for the global expansion of the phenomenon, although they first appeared in Japan (Gregory 2012).

Cahn's basic principles (in Seyfang 2006: 6) for TB functioning are: "recognising people as assets and that everyone has skills to share; redefining work to include the unpaid 'core economy' of work in the neighborhood and community; nurturing reciprocity and exchange rather than dependency; growing social capital; encouraging learning and skills-sharing; involving people in decision making". However, they vary in terms of their origins, functioning and purpose.

Boyle (2014) identified different streams of TBs around the world that either emerge from complementary currency initiatives (e.g., German) or from reciprocal volunteering systems (e.g., the UK, Japan and the US). This origin influences the expectations or goals attributed to time banking. We can differentiate three main purposes: social, political, and economic.

In the US and the UK, TBs have been traditionally promoted among the unemployed and other socially excluded groups (e.g., the elderly and the disabled) as a means to foster inclusion and equality (Del Moral 2013; Collom 2008; Kimmel 2008). Also, in Japan (Boyle 2014) TBs or Fureai Kippu date back to the 1970s and were linked principally to the participation and support of the elderly and retired (Boyle 2014; Hayashi 2012; Miller 2008).

Research suggests that they have targeted socially excluded and marginalized groups (Seyfang 2006b; Seyfang 2004; Seyfang and Smith 2002). In a similar line, the Accorderie model ${ }^{1}$ of time banking, developed in Quebec and then expanded in France, aimed at fighting social exclusion and poverty (Fare 2012). In the US, many TBs were created to facilitate access to services among the elderly in order to increase their well-being (Seyfang and Pearson 2000). In the UK, Seyfang (2002) depicts TBs as part of the social economy and as an improvement over volunteering, since they have attracted socially excluded groups more successfully than traditional volunteering. Research shows that TBs may improve employability by acquiring new skills at no cost, build

1 The Accorderie model is described as a community currency where all members have time accounts; no physical bills are exchanged (Fare 2012). When an exchange is carried out, one of the parties is debited with time and the other one is credited following the 'one hour equals one hour' principle, similarly to TBs in other countries. However, its main difference from TBs is that they also have a community credit program and a collective purchasing association. members' self-confidence and self-worth by putting in use their skills set and foster empowerment among members (Molnar 2011; Seyfang 2003).

Yet the possible social objectives of TBs are not limited to social inclusion. In Spain and Italy a large number of TBs emerged out of the feminist movement as municipal TBs (Boyle 2014; Del Moral 2013; Blanc and Fare 2013; Amorevole, Colombo and Grisendi 1998) to foster the work-life balance (Gisbert 2010). Their purpose largely focused on creating social capital and mutual assistance among older people (Blanc and Fare 2013; Miller 2008). In New Zealand they were fostered as a tool to strengthen ties among neighbors (Ozanne 2010; Ozanne and Ozanne 2011). Research on TBs in Sweden and UK concludes that they have proven successful as a tool to create social capital (Collom 2008; 2007; Molnar 2011).

In addition, time banking is presented as a political project. Cahn (2001) contended that time banking would promote co-production, recognising that everybody has skills to offer to the community especially when related to social and community services such as health and education. Time banking tried to fill one of the problems created by the current neoliberal model: the erosion of the Economy of Care, the impossibility of reaching full employment and the lack of social and political recognition of unpaid jobs (Gregory 2012; Kimmel 2008). Time banking challenges the system by promoting an entirely different set of principles than those found in the neoliberal paradigm (Seyfang 2006). For example, the principle of egalitarian remuneration is thought as a critique to how value and time are priced in the neoliberal capitalist market.

Therefore, as several authors advocate (Collom 2008; Seyfang 2006; Seyfang and Pearson 2000), TBs also hold political importance: they are a glimpse into an economy based on ethical values (Kimmel 2008). It is not surprising that they have been linked to the global justice movements (Del Moral 2013; Collom 2008) and have been traditionally seen as a form of disengagement from the market and of resistance to global capitalism. However, Hughes (2005) argued that these alternative trading spaces should be understood as reformist rather than radical building on previous work by Lee et al. (2004). Likewise, Dittmer (2013: 7) offers a more critical view of the potential of TBs as a tool in degrowth economies, as he contends that they are not well suited to advance alternative livelihoods or eco-localisation. At most, they can help strengthen ties in the community, and at worse, they may be a "cover for the neoliberal dismantling of the welfare state" or even contribute to the commodification of personal relations.

Finally, regarding the economic project, TBs are often depicted as a way of having access to services that users otherwise cannot afford (Collom, Lasker and Kyriakou 2012; Seyfang 2003). Also, as previously mentioned, recently the press has often con- 
veyed the idea of time banking as an alternative market for those hit by the recession. Boyle (2014) argued that in Italy and Austria, TBs attract those better-off but still hit by the crisis. On a different note, Del Moral (2013) explained that TB users may suffer from time poverty and look to cover real needs that emerge from their busy schedules (e.g., babysitting for working mothers). Yet although participants may be attracted by the possibility of obtaining material gains, different authors argue that TBs are ill-suited for this goal, given that there is no trade of goods and the limited availability of services (Dittmer 2013; Seyfang 2006; Lee et al. 2004). As Dittmer (2013: 9) suggested, TBs "do not support autonomy from formal employment" for their users, as for example a LETS may partially do.

Studies of TB members have also suggested this potential threefold role of TBs. The three main motives for joining a TB are political or ideological (e.g., fighting the current economic paradigm), economic (e.g., receiving services that they could not otherwise afford) and social (e.g., helping others and improving the neighborhood) (Collom, Lasker and Kyriakou 2012; Collom 2008; 2007; Seyfang 2002).

The profile of participants may largely define the purpose, level and type of activity of the TB, because of the skills they bring and because of their motives and preferences (Dubois, Schor and Carfagna 2014). For example, in Miller's thesis on Japanese TBs, it is argued that (2008, p.208): "the relative affluence of the aged in Japan, where retirees hold the greater share of private wealth, may mean that older Japanese draw more on time banks as a source of friends and pursuits to fill their time than as an alternative form of funding for help in any future dependency situation". Similarly, in other studies carried out in relatively affluent neighborhoods such as the first TB in New Zealand (Ozanne 2010), the Italian TB of Modena (Del Moral, 2013) or the Boston Time Trade Circle (Dubois, Schor and Carfagna 2014), the focus of the TB was not so much on co-production, but on strengthening the community and neighbors' relations.

Although TBs usually operate according to the same basic principles, there are differences in their organization and management. Molnar (2011) differentiates between person-to-person, person-to-agency, and agency-to-agency models. In most countries, the person-to-person model is the most frequent, but in the US, the UK and Sweden the person-to-agency model also exists (Collom 2007), coherent with the purpose of improving the efficacy of social welfare (Ozanne 2010). These agency-based TBs are similar to what Boyle (2014) calls a reward-based TB: people earn time credits from a sponsoring organization that may be a charity or a public service organization. The sponsoring organization defines the goals, activities and resources. TB users earn credits by helping other members and can spend these credits on rewards such as food banks and sports centers that also form part of this circle. Other variations could be found such as the Accorderie model that includes individual and collective exchanges such as community credit programs and members pooling their buying power together to negotiate directly with producers (Fare 2012). In addition, some schemes allow the participation of for-profit organizations (Dittmer 2013).

In the US and UK, there is also often a paid time-broker facilitating exchanges and invigorating the TB. In this case, TBs depend on public funds. Furthermore, in the US and the UK TB person-to-person exchanges are tax-exempt as they are considered as volunteerism (Dittmer 2013; Collom, Lasker and Kyriakou 2012), whereas in Sweden they are not (Molnar 2011). Therefore, a further consideration as regards the degree of support that TB may receive from the government, TBs are seen as schemes that encourage citizens' active participation in line with the 'Big Society' notion (Halsall et al. 2014; Del Moral 2013; North 2011).

\section{Method}

The research adopted a method-mixed approach (Johnson and Onwuegbuzie 2004), including a twophase data collection. First, a qualitative study of time brokers was carried out and second, a survey was distributed to members of TBs. Throughout the project, the researchers also followed the Facebook pages of four TBs, joined the Spanish Association for TB development and took part in two regional meetings of TB managers.

In the first stage, semi-structured interviews were conducted with time brokers of different TBs in Spain. The time brokers of our sample are not always employed unlike previous research in the US that shows that this is common in younger TBs (Collom, Lasker and Kyriakou 2012). Instead, some of the time brokers were TB users that would receive their payment in time credits or would have rotating shifts. A total of 28 interviews were conducted representing 28 different TBs. This decision was taken for two reasons. First, it allowed establishing rapport with the TB managers/time-brokers, the TB "gatekeepers" who facilitated the second phase of the fieldwork. In most cases, time brokers sent the questionnaire to the TB members and encouraged them to participate, while some forwarded it to other TBs with which they were in contact. Second, it allowed contextualizing the findings of the survey by understanding how TBs are managed.

For the selection of TBs, heterogeneous sampling was employed by identifying different characteristics to construct the sample (Patton 2002). Specifically, while most of the sample came from big cities such as Madrid or Barcelona, some TBs are located in smaller cities such as Girona and Tenerife or smaller 
villages (e.g., Ribagorza). Most TBs in our sample (around 64\%) were created in the last 5 years, while the oldest was created in 2003. In terms of membership, very different cases were included; from TBs with 4000 members to others with 10 members. At the time of writing the paper, two of the TBs in our sample have closed down (TB4, TB9); both originating from the $15 \mathrm{M}$ movement. Table 1 provides a description of TBs in terms of their characteristics.

To carry out the interviews with TB managers, a topic guide was developed to allow for more spontaneity and flexibility in information gathering; this guide became more detailed as the fieldwork proceeded. This was also necessary to ensure consistency as the interviews were carried out simultaneously by two different researchers. Interviews lasted from 30 minutes to one hour and took place during the months of January, February and March 2013.
In the second phase, self-administered questionnaires were sent to TB members, principally by email (via time brokers, TB Facebook pages and on the webpage of the Association for TB development). Targeting TB users via email was suggested by TB managers since it was usually the habitual means of communicating with members. Questionnaires were distributed during a meeting of the TB in only one case.

A total of 295 questionnaires were returned, of which 270 were valid. There are no studies that have quantified or described the universe (users of TB) with certainty. According to rough estimates by Boyle (2014), TB users in Europe may reach up to 200,000 members, whereas information provided by Julio Gisbert reveals 328 Spanish TBs but no specific information about the total number of users (Vivir Sin Empleo 2014).

Table 1.

Description of time banks

\begin{tabular}{|c|c|c|c|c|}
\hline TB & City & $\begin{array}{l}\text { Year of } \\
\text { creation }\end{array}$ & $\begin{array}{l}\text { Number of } \\
\text { users }\end{array}$ & Founders \\
\hline TB1 & Tenerife/ urban & 2010 & $240^{*}$ & Neighbors \\
\hline TB2 & Barcelona/ urban & 2011 & 57 & Town council and Salud y Familia Foundation (SFF) \\
\hline TB3 & Barcelona/ urban & 2011 & 59 & Neighbor Association and SFF \\
\hline TB4 & Valencia/ rural & 2012 & 20 & Group of friends $/ 15 \mathrm{M}^{\mathrm{b}}$ \\
\hline TB5 & Barcelona/Urban & 2006 & $200^{*}$ & Town council, SFF and 'Women and Community' Association \\
\hline TB6 & Barcelona/Urban & 2011 & 152 & Neighbor Association and SFF \\
\hline TB7 & Valencia/Rural & 2012 & 50 & Town council and Women's association (Casa de la dona) \\
\hline TB8 & Menorca/Urban & 2009 & $250^{*}$ & Grassroots initiative, SFF and help from another TB \\
\hline TB9 & Mallorca/rural & 2012 & 70 & $15 \mathrm{M}$ \\
\hline TB10 & Barcelona/Urban & 2003 & $200^{*}$ & Neighbor Association \\
\hline TB11 & Barcelona/Urban & 2007 & 83 & Barcelona Activa \\
\hline TB12 & Barcelona/Urban & 2012 & 30 & Neighbor Association and SFF \\
\hline TB13 & Girona/Urban & 2010 & 564 & Neighbor Association and SFF \\
\hline TB14 & Barcelona/Urban & 1999 & 300 & Neighbor Association \\
\hline TB15 & Madrid/Urban & 2009 & 80 & Association Ida y Vuelta \\
\hline TB16 & Valladolid/Urban & 2005 & 510 & Town Council \\
\hline TB17 & Madrid/urban & 2005 & 260 & Neighbors \\
\hline TB18 & Valencia/Urban & 2010 & 105 & Neighbor Association \\
\hline TB19 & Madrid/urban & 2011 & 105 & $15 \mathrm{M}$ \\
\hline TB20 & Online & 2012 & 4000 & Entrepreneurs \\
\hline TB21 & Huesca/rural & 2011 & 10 & Neighbors \\
\hline TB22 & Valencia/Urban & 2005 & 250 & Town council \\
\hline TB23 & Madrid/urban & 2006 & 56 & NGO Red Cross \\
\hline TB24 & Madrid/urban & 2011 & 30 & $15 \mathrm{M}$ \\
\hline TB25 & Madrid/urban & 2011 & 200 & $15 \mathrm{M}$ \\
\hline TB26 & Madrid/urban & 2011 & 76 & Neighbors \\
\hline TB27 & Madrid/urban & 2005 & 1031 & Town council \\
\hline
\end{tabular}

* The number is approximate as not all time brokers had strict control over the number of users.

a Salud y Familia is a private, not-for-profit association that provides consulting and guidance to new TBs in Spain (please see http://www.saludyfamilia.es/ ca/bancs-del-temps-cohesio-social/bancs-del-temps).

$\mathrm{b}$ These TBs originated from the $15 \mathrm{M}$ movement in Spain. 
According to the survey, the prototypical profile of their TB is a middle-aged woman with higher education (see Table 3 in Results). This confirms the information provided by TB managers in the interviews. Compared to the total Spanish population (according to Spanish Statistical Office data), women, the middle-aged, highly educated individuals and members of NGOs are overrepresented in the sample. A disadvantage of this sampling method is the risk of self-selection: it is likely that the most committed users will answer the questionnaire, and the inactive or uncommitted will be underrepresented. Although other sampling methods were considered (e.g., handing out the questionnaires during meetings, snowball sampling, etc.), according to the time brokers interviewed, the results were likely to be similar. In the sample, $20 \%$ of all respondents had never engaged in a TB exchange. This percentage is lower than the figure put forward by most TB managers (ranging from $40 \%$ to $80 \%$ depending on the TB). Therefore, it should be mentioned that the sample is likely to be biased towards the most active users.

Finally, the questionnaire included an initial six questions about engagement with the TB. Users were asked to report the month and year they joined the bank (tenure), the number of transactions carried out, the date of their last transaction and the services supplied and demanded.

Second, users were asked whether they engaged in other actions related to collaborative consumption (such as swapping and local currencies), volunteerism, or political participation (e.g., participation in social or civic associations). Third, consumers were presented with a list of goals and asked to recall and report what goals they were pursuing when they joined the TB. A modified version of the Taxonomy of Human Goals (Ford and Nichols 1987) was used (see Table 4 in Results).

\section{Results}

This section presents the main findings of the study and is structured into two main subsections: illusions and delusions. First, a description of TB is provided (goals and management of TBs and profile of users) and compared to other TBs described in the literature. The second section critically evaluates the articulation of TB in Spain, by explaining the main challenges found during the study.

\section{Illusions: goals of TBs and description of users}

All the TBs studied are person-to-person and work similarly to the type I TB, also coined as the babysitting circle, as specified by Boyle (2014). All the TBs use an egalitarian time-based measure of value: one hour equals to one hour regardless of the service. Services on offer and demand are fairly similar across TBs. However, contrary to Boyle (2014), who refers to Spanish TBs as homogeneous organizations, wide differences exist. To better account for these differences, a classification scheme or taxonomy is proposed, since this is a particularly useful tool in order to describe and structure a phenomenon about which little is known. Taxonomies organize "phenomena into mutually exclusive and exhaustive sets, with a series of discrete decision rules" (Dotty and Glick 1994). In the phenomenon under study, three decision rules are used to classify TB: (i) type of promoter; (ii) organization and functioning; and (iii) means of communication, since these emerge as the criteria that best capture differences among TBs (also see Del Moral 2013; Collom, Lasker and Kyriakou 2012; Seyfang and Pearson 2000). A summary of the decision rules and the corresponding schemes is found in Table 2.

According to the promoter, three types are identified. The promoter is key since it will shape the goals of the scheme and, to a large extent, its rules and procedures. In turn, as we will discuss later, the management (in particular, the existence of a time broker) will influence active participation.

(1) TBs created by town councils. Management of these banks is either outsourced to a local forprofit company (e.g., TB16 and TB22) or entrusted to social workers (e.g., TB21). These TBs are part of the Services to Families unit and are therefore closer to the vision of TBs as a tool to regain the work-life balance or to empower women.

(2) TBs created by neighborhood associations or neighbors and within nonprofit organizations and other associations (e.g., TB17, 18 and 26). The main aim of these banks was to create more and deeper social ties in the neighborhood by facilitating the creation of mutual support networks. Most TBs in the study started out as grassroots movements originating from neighborhood associations but some asked support from the local council. For example, the TB13 manager mentions:

Table 2.

Classification scheme of TBs in Spain

\begin{tabular}{|l|c|l|l|}
\hline According to the promoter & Town council & $\begin{array}{l}\text { Neighborhood association or Neighbors; } \\
\text { NPO and other Associations }\end{array}$ & Local assemblies \\
\hline According to the functioning & Horizontal or decentralized & Vertical or centralized \\
\hline According to the means of communication & Dominant online & Dominant offline \\
\hline
\end{tabular}

RIS [online] 2016, 74 (1), e028. REVISTA INTERNACIONAL DE SOCIOLOGÍA. ISSN-L: 0034-9712 
It was an initiative of this neighborhood. We have one of the highest rates of immigrants and traditionally some problems of racism. So, we decided to start the time bank and asked help from the local council, because there is a governmental program to reinforce education and coexistence in neighborhoods.

This reveals that TBs may result from a mixed topdown (legal or political framework for support of the initiatives by local authorities) and a bottom-up approach (as a grassroots movement) similarly to what has been observed among Italian banches del tempo (Del Moral, 2013). Also, depending on the neighborhood they may be more similar to the social inclusion model (e.g., TB13). A modified version of TBs that fits here is the solidarity bank. It is a grassroots movement operating on the basis of volunteers, but with no restrictions on exchanges or obligation for reciprocity. Their slogan is "I help you, you help me" to better adapt to the existing needs of the members. They have also created support groups to deal with painful experiences such as the loss of beloved ones. However, a paradox is that although it is a grassroots movement, this solidarity bank has been awarded prizes by local authorities for their humanitarian work and is recommended by public social services that lack resources to deal with all the cases they receive, especially those related to child and elderly care. Thus, the solidarity bank currently complements or even substitutes the existing social care system (Clary 2008).

A subversion of this type are TBs created within nonprofit organizations (e.g., TB15 and 23) similar to those described by Collom, Lasker and Kyriakou (2012). Their primary aim is to improve the social fabric of local communities. In certain cases they may also be more selective. For example, TB7 was founded by a women's association and would only accept women as TB members.

(3) TBs created by local assemblies. These TB emerged after the 15M movement (e.g., TB4, TB9, TB24). While they share the aim of creating social capital, they have other goals such as experimenting or putting into practice new economic relationships not mediated by the markets or showing others that there are exchange models other than the traditional capitalist market. As the TB4 manager argued though, they lacked any support from the local council to carry on with the TB and that constituted an important barrier for the TB growth along with issues of participants' decreasing motivation.

The previous description suggests that there is a relationship between the promoter and the main goal assigned to the TB. For example, the goal is more political in TB born from assemblies, whereas it becomes more oriented towards the creation of social capital in TB stemming from neighborhood associations. Moreover, this categorization shows that time banking is not a homogenous project in Spain, but fragmented, given that many possible goals are attached to the schemes.

The second criterion for categorizing TBs relates to their organization and functioning; in particular, according to the level of mediation of time brokers, two types of TB were found: the horizontal or decentralized and the vertical or centralized type. In the vertical TB, the time broker figure is prominent in different stages of the transactions. Users explain their offers and demands to the TB broker and s/he acts as an intermediary by matching the demand and the offer. Specifically, the broker contacts both parties and gives them each other's contact details leaving it to them to arrange an appointment. Otherwise, the parties will meet at the headquarters of the TB and arrange a future appointment. Afterwards, users will contact the time broker after the transaction to credit/ debit their time accounts.

In the horizontal TB, members do not need to contact directly with the TB to ask for a service. They usually receive an updated list of all the services offered or check them directly in the online application (if the bank operates online), so they choose directly from the directory and contact the other party. In those cases, the time broker's role is more focused upon other tasks (i.e., attracting and maintaining users, encouraging exchanges, organizing group exchanges). Nevertheless, hybrid variations can be found such as TBs that are horizontal, but the time broker may mediate transactions for older members that cannot use online directories or for members without Internet access.

Other TBs have volunteer time brokers that are paid in time. In contrast, municipal TBs have a paid position for this role. The unpaid function of time broking translates into slower rhythms and efficiency, tiredness (and likely resignation) of the volunteers and, potentially, the dissatisfaction of members.

Since the final sample comprised both types of TB, the respective time brokers explained the advantages and disadvantages of these approaches. In the case of vertical TBs, exchanges are mediated by the time broker who is in charge of selecting the best possible fit for each service requested according to the needs and idiosyncrasy of the requesting party. This increases trust among TB participants as well as the likelihood that the exchange will be successfully completed and evaluated. Other potential benefits of vertical TBs are that users avoid the "embarrassment" and effort of having to "negotiate" with other members, especially strangers (Molnar 2011).

Horizontal TBs are faster and more efficient. As the time broker of TB13 stated: "Two minutes and the problem is solved". If exchanges are mediated by time brokers, then they are subject to their availability and the TB office hours. However, we found that in horizontal TBs where TB brokers are almost nonexistent, there are fewer exchanges to the point of total 
inactivity of the TB (e.g., TB19, TB21). TB13 is an exception as it is a very active horizontal TB whose brokers actively participate in keeping records of the TB's activity, encouraging more exchanges, and so on, which reinforces the crucial role of time brokers as "exchange propellers".

Finally, according to the principal means of communication, we distinguish between dominant online and dominant offline TB. There are two communication flows: between time brokers and users and among users. In many TBs, time brokers send emails to the users with news about the TB, updated lists of the services offered and upcoming events. Other TBs, such as TB1, have forums. Many TBs also have a Facebook page where all members can interact. Members may post a need they have, time brokers inform members about new services and upcoming events or pictures and comments on previous events. However, this depends on the profile of the participants. For example, most participants in TB3 are older and not keen on information technology, so communication through e-mails was ruled out. Instead, they prefer communicating offline with meetings at their office or by sending printed newsletters. It is straightforward that online TBs hold a greater potential of being horizontal. Moreover, the management of the TB varies, encompassing online and offline elements and devices; from handwriting credited and debited time accounts and using checkbooks to online software and online time accounts.

The majority of TBs in our sample organize meetings on a frequent basis. TB6, for example, meets once a month to discuss the project, while other TBs organize group exchanges such as yoga or English classes. These activities and meetings are deemed crucial by TB managers, since they build trust and lead to further person-to-person exchanges.

In this sense, the existence of a permanent physical space that acts as the TB office is also relevant with regards to how and where members communicate. As previously mentioned, if TBs have some type of support from local town councils, they often have a designated space to hold their meetings, register members, or carry out group or individual exchanges, among others. For example, most TBs in Barcelona (e.g., TB2, 3, 5, 6) have an office within larger community centers and can use the space on specific day/s of week. Nevertheless, when this is not the case, the time brokers have to employ creative strategies to find a space to meet and interact in person.

In dominant online TBs (TB20) both communications and services take place online. The manager of the TB20 explained that they created a website to facilitate the personal trade of services since few transactions were carried out face-to-face: most people prefer to exchange services online. Furthermore, purely online TBs do not restrict membership to specific neighborhoods, which has traditionally been a common criterion of exclusion for membership
(Collom, Lasker and Kyriakou 2012). These TBs are more similar to knowledge banks since the services exchanged are knowledge-based (e.g., professional advice, career coaching, translation services, among others). Surprisingly, the number of transactions carried out and the total membership of this online TB was greater than other older TBs. This may be due to different reasons: the nature of the services exchanged requires less trust among participants; people are more used to sharing on the Internet; or the transaction time (i.e., speed of the offer and demand match and service provision), which is clearly lower in online TB.

To sum up, TBs in Spain are rather fragmented. Although they share some common features (e.g., egalitarian value), they pursue different goals and are organized very differently. This description reinforces the idea of TBs as "chameleonic" devices that are instrumental for different purposes, albeit enhancing social capital is the dominant one.

Regarding the profile of users, our survey shows that the average TB user is female, middle-aged has a university education and children. The feminization of TB has been reported in other studies and is not exclusive to Spain (Boyle 2014). Previous research has also found that women tend to predominate in community currencies because they give value to the informal, non-marketized work usually offered by women (Del Moral 2013; Collom, Lasker and Kyriakou 2012; Seyfang 2001). In their comparison of three US TBs, Collom, Lasker and Kyriakou (2012) found that members living alone represented 40 to $60 \%$ of members, which clearly does not apply here. The limited membership among the eldest (4\%) and the segment with no schooling (6\%) is significantly lower than other studies (Seyfang 2002; Collom 2008). In Seyfang and Smith (2002), for example, over $40 \%$ of participants are of retirement age. However, Collom, Lasker and Kyriakou (2012) argued that historically TB tended to attract the elderly because of their community building orientation, but they found that TB founded after 2009 had an underrepresentation of elderly in their membership. Dubois Schor and Carfagna (2014) also found younger members to be overrepresented. In our sample, $24.9 \%$ were unemployed, which is roughly representative of the unemployed Spanish population in recent years. This may suggest that TB do not contribute to the social inclusion of the marginalized and unemployed. However, these results may be due to the fact that the survey was predominantly online.

The majority of TB users do not appear to be households stricken by poverty, unemployment and vulnerability as in other types of community currencies that have grown in times of crisis like the Argentine Red de Trueque (Gomez and Helmsing 2008). Due to the economic situation in Spain, the percentage may have been expected to be significantly higher. Furthermore, TB brokers explicitly disagree with the 
view of TBs as shelters and relief providers for the jobless. TBs do not seem to contribute to local economic regeneration by providing a secondary source of income for the poor and unemployed like the Argentine Red de Trueque (Gomez and Helmsing 2008). Time brokers disagree that unemployed members have increased in recent years, arguing that the TB is not a place "where people can satisfy basic needs"; rather, they believe that the participation in TBs is a way to "stay busy" and boost self-esteem by exercising skills that are not otherwise offered. This result confirms previous framings of time banking as a social rather than an economic-utilitarian project (Seyfang and Longhurst 2013a; b) for the Spanish context.

One out of 10 respondents joined the TB before 2008; 13\% more until 2011 and the rest from 2011 onwards. Six out of 10 are new members, since they have joined in the last two years (2012-2013). This is consistent with the growth of the TB phenomenon reported in the media.

In relation to their lifestyle, a minority of the respondents fit in with what can be labelled as community-engaged lifestyles, since they carry out other collaborative activities and do volunteer work. For example, 4 out of 10 users take part in other forms of sustainable consumption, such as swapping (40.5\%) or second-hand buying (43.2\%), but only a marginal 10 percent participates in local currency schemes. Approximately 3 out of 10 do some form of volunteer work. Conventional political engagement (i.e., membership in political parties or trade unions) is also marginal $(18 \%)$, while the percentage of those participating in the local assembly movement is slightly higher $(21 \%)$. This is not surprising given that some TBs have emerged from this movement.

Thus, the description of TB users suggests that TBs have successfully attracted citizens that are not volunteers elsewhere nor do they have an intense political orientation, as also found in Molnar (2011). Consistent with previous authors (Boyle 2014; Molnar 2011), TBs seem to attract the 'mainstream' social groups. Although TBs remain rather reformist (Dittmer 2013), they have become a valid option for participation, empowerment and social capital creation for people who do not form part of other movements.
Finally, regarding the motivational profile, the descriptive statistics show that the most common goals are integrative (i.e., belongingness, social responsibility, equality and resource provision, $64 \%$ ) followed by expressive goals (i.e., protesting against the system, setting an example, $48 \%$ ), cognitive goals (i.e., understanding and intellectual creativity, $42 \%$ ) and subjective organization goals (i.e., unity and transcendence). ANOVA and t-tests do not reveal differences.

In line with previous criticisms regarding the economic potential of TBs (Dittmer 2013; Lee et al. 2004), obtaining a material gain is mentioned by only $44 \%$ of participants (to a larger extent by the unemployed, $p$-value <0.05). This shows that, for the majority of respondents, the principal motivation to join the TB is not economic although such discourses have been constructed in international media in recent years. Instead, goals such as creating a community or protesting against the current system emerge as a more widespread response. Previously, Collom, Lasker and Kyriakou (2012) found that TB members were guided principally by practical, social and ideological considerations.

Therefore, according to these results, participants seek to improve their relational capital, cultural capital and, less importantly, their material capital (see Ozanne 2010) through their participation. Interestingly, their participation indeed holds an expressive function: protesting against the system or showing that a different economy is possible, even in cases where the TB was not initially created with a political dimension (emerging from the assembly movement).

Hence, on the one hand participants join because they want to make a statement and express disagreement with the current status quo. On the other hand, the integrative goals mentioned by the participants shows the need for stronger communities that people can rely on and the desire to be altruistic. People join because they want to help, rather than being helped. These findings reflect the need to seek collective solutions to the dismantlement of the welfare state in times of crisis, rather than simply a network where individuals can obtain free services.

Table 3.

Description of respondents

\begin{tabular}{llllll}
\hline Gender & Men 31.7\% & & Women 68.3\% & \\
\hline Age & $18-2910.6 \%$ & $30-4958.7 \%$ & $50-6426.8 \%$ & Over 65 3.9\% & \\
\hline Education & No studies 6\% & Primary 4.5\% & Secondary 6.2\% & Intermediate 17.5\% & University 71.2\% \\
\hline Type of household & Alone 25.7\% & Couple with no children & Couple with children & Alone with children & Living with parents \\
& & $41.5 \%$ & $23.4 \%$ & $7 \%$ & 2.3\% \\
\hline Employment & Employed 59.6\% & Unemployed 24.2\% & Student 3.9\% & Retired 9\% & Housewife 3.4\% \\
\hline Member NPO & No 49\% & Yes 51\% & & & \\
\hline
\end{tabular}


Table 4.

Description of goals

\begin{tabular}{|c|c|c|}
\hline Type of goals ( $\%$ of individuals choosing at least one goal of this type) & Focal goal & $\%$ \\
\hline \multirow{3}{*}{ Affective goals $(62.8 \%)$} & Entertainment & 47.1 \\
\hline & Happiness & 32.2 \\
\hline & Physical well-being & 27.3 \\
\hline \multirow{4}{*}{ Cognitive goals $(77.7 \%)$} & Exploration & 37.2 \\
\hline & Understanding-gaining knowledge & 62.8 \\
\hline & Intellectual creativity & 52.1 \\
\hline & Positive self-evaluation & 32.2 \\
\hline \multirow{2}{*}{ Subjective organizational goals $(61.2 \%)$} & Unity & 48.8 \\
\hline & Transcendence & 34.7 \\
\hline \multirow{4}{*}{ Self-assertive social relationship goals $(43.8 \%)$} & Individuality_feeling unique & 6.6 \\
\hline & Self-determination & 31.4 \\
\hline & Superiority & 10.7 \\
\hline & Resource acquisition-obtaining approval & 7.4 \\
\hline \multirow{4}{*}{ Integrative social relationship goals (95.1\%) } & Belongingness & 59.5 \\
\hline & Social responsibility & 60.3 \\
\hline & Equality & 56.2 \\
\hline & Resource provision & 77.7 \\
\hline \multirow{4}{*}{ Task goals $(71.1 \%)$} & Mastery & 47.1 \\
\hline & Task creativity & 27.3 \\
\hline & Management-maintaining order & 29.8 \\
\hline & Material Gain & 46.3 \\
\hline \multirow{2}{*}{ Expressive $(69.4 \%)$} & Protesting against system & 55.4 \\
\hline & Showing others to be responsible & 43.8 \\
\hline
\end{tabular}

Moreover, although citizens join TBs because they want to learn (cognitive goals are chosen by most participants), it does not seem that they are being used as a way to improve employability skills. The most frequent type of services offered and demanded (i.e, cooking lessons, crafts) suggest that members are trying to acquire other skills, not necessarily those sought and rewarded in labor markets. This "recreational and experiential" feature of Spanish TBs suggests that the majority of services are not highly skilled (Dittmer 2013; Seyfang 2006), but it also shows what participants principally look for as other services are also available.

The findings also show that the motivations of TB users mirror the goals of TBs, with one difference: users report having cognitive goals that are not acknowledged by time brokers when explaining the project in the interviews.

\section{Delusions}

So far we have depicted TB as heterogeneous schemes of increasing popularity. They have attracted mainstream users that see in TBs a kaleidoscopic project that combines political, social, and economic dimensions.
However, this view of TBs contrasts with the limited activity being carried out within them. One fourth of respondents have never engaged in a transaction in the TB; hence, they can be considered "inactive". Three out of 10 reported having carried out a transaction more than one month before the survey. Half of respondents are "recent" users and made a transaction in the last month $(12 \%)$, in the last two weeks $(7 \%)$, in the last week $(25 \%)$ or the day before the survey $(6 \%)$. On average, respondents reported making 2.1 transactions (the maximum being 6) since they joined the TB. This mean figure hides important differences among respondents: $35.5 \%$ report having made one or less transactions, while only $6 \%$ are frequent users, having made 5-6 transactions since they joined the TB. No relationship is observed between lifestyle and engagement, nor does it seem to vary according to the demographic subtypes.

This marginal use of TBs for exchanges contrasts with the symbolic importance attached to time banking as a social and political project. Actually, the lack of exchanges is the reason why two of the TBs studied have officially closed down and another two keep their activity at a minimum. If users do not exchange services, the sustainability of the TB is jeopardized, and with it, the potential achievement of social and political goals. Interestingly, group exchanges are more popular than person-to-person exchanges. 
The remainder of this section discusses why this occurs and unveils the challenges of time banking in Spain: the supply and demand mismatch, the type of services on offer/demand, the inherent inflexibilities and inefficiencies of the model, and the users' "psychological barriers", including reluctance to request services.

As they stand, TBs face many limitations to becoming an alternative market. As the online survey shows and the TB managers acknowledge, there is a mismatch between offer and demand. Participants seem to demand pleasurable experiences and technical expertise (hedonistic and functional services). Indeed, the t-tests show that demand is significantly higher than the offer for computer assistance, massages, and other beauty-related services such as hairdressing ( $p$-value $<0.05)$. In contrast, the t-tests show that participants tend to offer significantly more altruistic, caring services such as looking after others (animals, elderly or children) ( $p$-value $<0.05$ ). Moreover, this portfolio of services questions the potential of TBs to become a sustainable alternative to conventional markets since the services offered, such as dog walking, vegan cooking lessons or knitting classes, do not fulfill basic needs. As the TB4 manager explained:

Some people justified not using the services because they say: "the bank does not pay my mortgage". They see it as a complement in the consumer society we live in. [...] Some people just do not see it as a real alternative.

The main reason given in the literature (Dittmer 2013; Seyfang 2006; Lee et al. 2004) to explain this problem is that the valuation of work, one of the basic principles of time banking, makes users offer only those skills and services that will not be valued in the conventional market; skilled providers go to the conventional market since they feel undervalued (Dittmer 2013). Moreover, trying to "get something done" is a time-consuming, "inefficient" experience that demotivates people who go to conventional markets for "urgent" things. In line with Dubois, Schor and Carfagna (2014), consumer socialization in mainstream markets negatively affects TB exchanges in that TB users do not stop looking for the professional services they can find in these markets. The following quote (TB8) evidences this problem:

For instance, my mother is a member of the time bank and she cannot handsew, she needs someone to handsew her trousers. But this means: she has to call us, then she has to give the information, we find the person, they arrange when to meet, she brings him her trousers and then the other person does it for her. And in this case it is for free, but it is a slower process. And my mother has credit, like 5 hours, because she has participated doing different things. But she will probably just take the trousers to the shop and have it done for
5-6 euros. The rhythm of society is fast. You probably prefer to pay the 6 euros and have it done now! And this is a problem that we have, everything is like fast food!

Hence, if they have to compromise on the quality, convenience and the speed of delivery in TB exchanges, they might just opt for the market. In the aforementioned quote, getting a service in the TB appears to be the slowest and most complicated choice and is thus ignored as an option because of its lower utility for the user. The evaluation of TB exchanges on that basis affects the long-term ongoing participation of users. Furthermore, most TB brokers are categorical and emphasize that TBs do not wish to harm in any way the self-employed and smaller firms that have suffered greatly during the crisis.

We have to keep an eye on that. We do not want to take other people's, working people's jobs. You can ask someone to come one day and pick up your children from kindergarten, but not every day. Because by doing so you are replacing a person whose job is exactly this; taking care of children. Time banking should be sporadic exchanges. (TB6)

But beyond that, there are "psychological barriers" (Ozanne 2010) that make users try paid services first. Some TB managers (e.g., TB15, TB19) suggest that the main problem is not that they do not have the services users are looking for, but that users do not even think of the TB as a potential space for finding such services. The TB is not a salient option for users. This reinforces the role of time brokers as a constant reminder of TBs as a potential space for meeting needs.

The most prominent "psychological barrier" is the reluctance to request services, which according to time brokers, is the main reason why exchanges do not occur. TBs attract many people that are willing to offer services and to help but do not request services in return. This is probably due to the fact that they do not feel in need or because they resort to professional providers when they are in need of a service. The roots of this reluctance to ask for help should be explored in future studies.

\section{Conclusion}

This study provides a broad description of Spanish TBs on various levels: in terms of their design and functioning (organizational-meso level) and in terms of participants, their goals and engagement with the TB (micro level). Both dimensions are important in order to understand how the TB project is positioned in the current political and social context of Spain.

In terms of organization, a taxonomy of Spanish TBs is offered along three dimensions: according to the promoter, according to their functioning and ac- 
cording to their means of communication. The findings show that TB are heterogeneous and their differences affect the way they operate and the potential continuance of the project. We have also brought attention to TBs that emerged from the $15 \mathrm{M}$ movement as a response to the current social situation in Spain.

The findings of this study show that Spanish TBs share some similarities with those in other countries, but retain specific features. For example, the agency model of TB is not found. Similarly to previous research on TBs, our findings emphasize the social dimension of time banking in Spain: TBs are more oriented towards social capital creation and specifically to improving the social fabric of the neighborhood. This is the dominant role of Spanish TBs: to provide a structure to develop social networks, build trust, and reinforce social ties.

In line with the criticisms regarding the limited economic potential of TBs (Dittmer 2013), the utilitarian view of time banking does not seem that prominent in Spain. Collom, Lasker and Kyriakou (2012) found that members of some TBs use them mainly for practical reasons to cover real needs. However, other authors, such as Seyfang (2002) and Del Moral (2013), coincide with our findings: TBs are used partially to cover specific needs such as repairs, but not principally. The profile of the TB members in our study also confirms this. Moreover, this study contends that users do not see TBs as a source of use value for various reasons, thus jeopardizing the social and political value of the project.

This seems to be a paradox: users join because they are attracted by the social and political dimension of the project, but unless TBs become a way of meeting users' needs and solving problems, they will not fulfill their potential and ensure their continuance. Here is where the delusion arises: the belief that TBs can continue to exist in their current form and that they are providing mutual support, when they are actually doing so in a very limited way. To some degree, our findings confirm previous claims that the majority of services are not highly skilled (Dittmer 2013), meaning that TB users have easy access to informal services such as babysitting or massages. Most importantly, however, we found that time banking is not a salient option for users who might opt for the market when they have a real need. This may happen either because they seek professional services or because TB exchanges involve a more complicated and time-consuming process. Furthermore, we found that many TB users offer their services but do not request any, thus violating the notion of reciprocity (see, for example, Collom, Lasker and Kyriakou 2012; Molnar 2011). This suggests that they may see TBs as spaces for volunteering where they can 'provide' their services guided by altruistic motives, but do not perceive themselves to be 'in need' or as potential recipients in TB exchanges.
Time banking may be seen as another space for civic engagement that participants use to distance themselves from the market-understood not as a space for satisfying needs, but as the metonym of the neoliberal system and its values of competition, individualism, selfishness, and so on. In line with other authors (Forno and Graziano 2014; Castells, Caraca and Cardoso 2012), participants seem to look for meaning in different aspects of their daily lives. Thus, their participation holds more of a symbolic significance rather than a functional utility: by joining a TB users may feel they are symbolically fighting the current neoliberal globalization, since TBs stand for "anti-neoliberal" values, such as care, inclusiveness or equality (Alberich 2014). Nevertheless, such a view may be criticized since TBs can be promoted in line with the notion of the 'Big Society', but they place more responsibility on citizens and local communities while the welfare state is dismantled (Del Moral 2013; North 2011).

Future research should explore the dynamic interrelation of these spaces with other social actors such as other grassroots movements, peer pressure groups or local government authorities. A challenge is whether TBs are a passing fad or whether they will continue expanding in the near future. In that sense, it remains to be seen whether they are spaces of transition between social paradigms to a lesser or greater extent.

\section{References}

Alberich, T. 2014. "Movimientos sociales, responsabilidad corporativa e inclusión social en la globalización". Revista Internacional de Sociología 72(1): 113132. http://dx.doi.org/10.3989/ris.2013.03.04

Amorevole, R., Colombo G., and Grisendi A. 1998. Le banque del tempo. Milano: Franco Angeli.

Blanc, J., and Fare M. 2013. "Understanding the role of governments and administrations in the implementation of community and complementary currencies". Annals of Public and Cooperative Economics 84(1): 63-81. http://dx.doi.org/10.1111/ apce. 12003

Blanc, J. 2011. "Classifying 'CCs': Community, complementary and local currencies' types and generations". International Journal of Community Currency Research 15: 4-10.

Boyle, D. 2014. "The Potential of Time Banks to support Social Inclusion and Employability". JCR Scientific and Policy Reports, Report EUR 26346 EN. European Commission, Joint Research Centre.

Cahn, E. 2001. No More Throw-Away People: The CoProduction Imperative. Washington DC: Essential Books.

Castells, M, Caraca, J.E. and Cardoso, G. 2012. Aftermath: The cultures of Economic Crisis. Oxford: Oxford University Press.

Clary, B. 2008. "Volunteer Management in Community Currency Systems: An Examination of Time Banks". Pp. 91-120 in M. Allen \& L. Troth (eds), Challenges in Volunteer Management. Washington: IAP Information Age Publishing. 
Collom, E. 2007. "The motivations, engagement, satisfaction, outcomes, and demographics of time bank participants: survey findings from a US system". International Journal of Community Currency Research 11: 36-83.

Collom, E. 2008. "Engagement of the elderly in time banking: The potential for social capital generation in an aging society". Journal of aging \& social policy 20(4): 414-436. http://dx.doi. org/10.1080/08959420802186282

Collom, E. 2011. "Motivations and Differential Participation in a Community Currency System: The Dynamics Within a Local Social Movement Organization". Sociological Forum 26(1): 144-168. http://dx.doi. org/10.1111/j.1573-7861.2010.01228.x

Collom, E., Lasker, J.N. and Kyriacou, C. 2012. Equal Time, Equal Value Community Currencies and Time Banking in the US. Surrey: Ashgate.

Del Moral, L. 2013. "Espacios comunitarios de intercambio, bienestar y sostenibilidad de la vida: estudio de casos sobre bancos de tiempo en un contexto europeo." PhD dissertation, Universidad Pablo de Olavide, Sevilla, Spain.

Dittmer, K. 2013. "Local currencies for purposive degrowth? A quality check of some proposals for changing money-as-usual". Journal of Cleaner Production, 54: 3-13. http://dx.doi.org/10.1016/j. jclepro.2013.03.044

Doty, D.H., and Glick, W.H. 1994. "Typologies as a unique form of theory building: Toward improved understanding and modeling". Academy of Management Review 19(2): 230-251.

Dubois E.A., Schor J.B. and Carfagna L.B. 2014. "New Cultures of Consumption in a Boston Time Bank". Pp. 95-124 in J. Schor and C. Thompson (Eds.), Sustainable Lifestyles and the Quest for Plenitude: Case Studies of the New Economy. New Haven: Yale University Press.

Ekeh, P.P. 1974. Social Exchange Theory: The Two Traditions. Cambridge: Harvard University Press.

Eunjung Cha, A. 2012. "Spain's crisis spawns alternative economy that doesn't rely on the euro." The Guardian. Retrieved June 172013 (http://www.guardian.co.uk/ world/2012/sep/04/spain-euro-free-economy).

Fare, M. 2012. Community Currencies and Self-Help Networkd: The Case of the Accorderie. Paris, France: Veblen Institute for Economic Reforms.

Ford, M.E. and Nichols, C.W. 1987. "A taxonomy of human goals and some possible applications". Pp. 289311, in M. E. Ford and D. H. Ford (eds.), Humans as self-constructing systems: Putting the framework to work. Hillsdale, NJ: Erlbaum.

Forno, F. and Graziano, P. 2014. "Sustainable community movement organisations". Journal of Consumer Culture 14(2): 139-157. http://dx.doi. org/10.1177/1469540514526225

Frayer, L. 2012. "Time Banks' Help Spaniards Weather Financial Crisis." US National Public Radio (online). Retrieved June 172013 (http://www.npr. org/2012/09/22/161380937/time-banks-helpspaniards-weather-financial-crisis).

Gomez, G.M and Helmsing, A.H. 2008. "Selective Spatial Closure and Local Economic Development: What Do We Learn from the Argentine Local Currency Systems?". World Development, 36(11): 2489-2511. http://dx.doi.org/10.1016/j.worlddev.2007.11.015
Gisbert, J. 2010. Vivir sin empleo. Madrid: Los libros del lince.

Gregory, L. 2012. "Improving health through participation: time banks as a site for co-production." PhD dissertation, Cardiff University, UK.

Halsall, J.P., Wankhade, P. and Cook, I.G. 2014. "The Big Society Debate: Is it a Panacea for Reducing the Impact of Welfare Cuts in Public Health?". World Journal of Social Sciences 4(1): 167-175.

Hayashi, M. 2012. “Japan's Fureai Kippu Time-banking in Elderly Care: Origins, Development, Challenges and Impact". International Journal of Community Currency Research 16: 30-44.

Hughes, A. (2005). "Geographies of exchange and circulation: Alternative trading spaces". Progress in Human Geography 29(4): 496-504. http://dx.doi. org/10.1191/0309132505ph563pr

Johnson, R.B., Onwuegbuzie, A.J., and Turner L.A. 2007. "Toward a definition of mixed methods research". Journal of mixed methods research 1(2): 112-133. http://dx.doi.org/10.1177/1558689806298224

Kimmel, S.D. 2008. "Beyond volunteerism: Timebanking as a catalyst for community and economic regeneration", Social Policy Fall: 4-9.

Lee, R., Leyshon, A., Aldridge, T., Tooke, J., Williams, C.C. and Thrift, N., 2004. "Making geographies and histories? Constructing local circuits of value". Environment and Planning D: Society and Space 22(4): 595-617. http://dx.doi.org/10.1068/d50j

Martínez López, M. 2003. "Los movimientos sociales urbanos. Un análisis de la obra de Manuel Castells". Revista Internacional de Sociología 61(34): 81106. http://dx.doi.org/10.3989/ris.2003.i34.285

Miller, E.J. 2008. "Both Borrowers and Lenders: Time Banks and the Aged in Japan." PhD Dissertation, Australian National University, Australia.

Molnar, S. 2011. "Time is of the essence: The challenges and achievements of a Swedish time banking initiative". International Journal of Community Currency Research 15: 13-22.

North, P. 2003. "Time Banks - Learning the Lessons from LETS?" Local Economy 18(3): 267-270. http:// dx.doi.org/10.1080/0269094032000111048

North, P. 2011. "Geographies and utopias of Cameron's Big Society". Social \& Cultural Geography 12(8): 817-827. http://dx.doi.org/10.1080/14649365.201 1.618889

Ozanne, L.K. 2010. "Learning to exchange time: Benefits and obstacles to time banking". International Journal of Community Currency Research 14(20): 1-16

Ozanne, L.K. and Ozanne, J.L. 2011. "Building the strength of local community through time bank exchanges", European Advances in Consumer Research, 9. Retrieved June 142014 (https://www7511.ssldomain.com/acrwebsite/assets/PDFs/European $\% 20$ ACR\%20Proceedings\%20Vol\%209.pdf).

Patton, M. Q. 2005. Qualitative research. London: John Wiley \& Sons, Ltd. http://dx.doi. org/10.1002/0470013192.bsa514

Seyfang, G.J. and Pearson, R. 2000. "Time for Change: International experience in community currencies". Development 43(4): 56-60. http://dx.doi. org/10.1057/palgrave.development.1110197

Seyfang, G.J. 2002. "Time on our side: Time banks and active citizenship". New Economy 9(4): 242-247. http://dx.doi.org/10.1111/1468-0041.00278 
Seyfang, G.J. and Smith, K. 2002. "The Time of Our Lives: Using Time Banking for Neighbourhood Renewal and Community Capacity Building". London: New Economics Foundation.

Seyfang, G.J. 2003. "Growing cohesive communities one favour at a time: social exclusion, active citizenship and time banks". International Journal of Urban and Regional Research 27(3): 699-706. http://dx.doi.org/10.1111/1468-2427.00475

Seyfang, G.J. 2004. "Consuming values and contested cultures: a critical analysis of the UK strategy for sustainable consumption and production". Review of Social Economy 62(3): 323-338. http://dx.doi. org/10.1080/0034676042000253936

Seyfang, G.J. 2006. "Sustainable consumption, the new economics and community currencies: developing new institutions for environmental governance". Regional Studies 40(7): 781-791. http:// dx.doi.org/10.1080/00343400600959173

Seyfang, G.J. and Longhurst, N. 2013a. "Growing green money? Mapping community currencies for sustainable development". Ecological Economics 86: 65-77. http://dx.doi.org/10.1016/j. ecolecon.2012.11.003

Seyfang, G.J. and Longhurst, N. 2013b. "Desperately seeking niches: Grassroots innovations and niche de- velopment in the community currency field". Global Environmental Change 23(5): 881-891. http:// dx.doi.org/10.1016/j.gloenvcha.2013.02.007

Vivir sin Empleo. 2014. "Situacion de los bancos de tiempo en espa-a en junio de 2010 y guia para la creacion de bancos de tiempo." Spain. Gisbert, J. Retrieved June 11 2014. (http://www.vivirsinempleo.org/2010/05/situacion-de-los-bancos-detiempo-en.html).

Yamagishi, T, and Cook K.S. 1993. "Generalized Exchange and Social Dilemmas". Social Psychological Quarterly 56: 235-248. http:// dx.doi.org/10.2307/2786661

CARMEN VALOR, Lecturer at the Universidad Pontificia Comillas (Spain). Her work focuses on sustainable consumption. Previous research by the author has been published in Journal of Business Ethics, Journal of Consumer Policy and Journal of Marketing Management, inter alia.

ELENI PAPAOIKONOMOU, Lecturer of Marketing at Rovira and Virgili University. Her work has been published in the Journal of Business Ethics, Journal of Consumer Culture and International Journal of Consumer Studies, among others. 